\title{
Social Care for HIV/AIDS Patients in Spain
}

\author{
Consuelo López Fernández ${ }^{1 *}$, Juan Manuel Picardo Garcia², Ma Jose Santi Cano ${ }^{3}$, Veronica Perez Cabezas ${ }^{3}$ and MaJoseAbellan Hervas ${ }^{3}$ \\ ${ }^{1}$ University of Cadiz Jerez de la Frontera, Cádiz Spain \\ ${ }^{2}$ Department of Psychology, University of Cadiz Jerez de la Frontera, Spain \\ ${ }^{3}$ Department of Nursing and Psychotherapy, University of Cadiz Jerez de la Frontera, Spain
}

In the early 80s it was diagnosed in Spain the first case of Acquired Immunodeficiency Syndrome, AIDS, in a social context of a large contingent of injected drug users (IDUs). HIV prevalence reaches over $50 \%$ in this high risk group, affecting young adults, and spread by heterosexual and perinatal transmission [1]. In the 90s, Spain had one of the highest rates of AIDS in Europe, and it was the leading cause of years of potential life lost (YPLL) in men and the second one in women. Prevention programs and the emergence of antiretroviral drugs marked a turning point in the evolution of the epidemic changes in risk behaviors, slowing the progression of the epidemic. The aim of this review was to identify the social care for HIV/AIDS patients in Spain. The review question was: 'What information has been reported when describing health and social care to HIV/AIDS patients in Spain? The search strategy underwent several iterations of peer review before being finalised. The search was completed with nine electronic databases (CAB-Health, DIALNET, MEDLINE, Scopus, Cochrane Library and Web of Science) and different governmental sources (i.e. INE). The same search protocol was translated for each of the databases. Situation of HIV infection in Spain Currently, the overall rate of new cases of HIV is similar in other European countries, and since 2004, a decrease of cases in IDUs and an increase in men who have sex with men (MSM) has been observed [2]. In 2013, Spain, with a population of 46,591,857 inhabitants, reported 3278 new infections, of which, $85 \%$ weremenwithanaverageageof35years. The mostfrequent transmission form was the unprotected sex between men $(51.2 \%)$, followed by heterosexual transmission (28.5\%), and with a greater distance, parenteral transmission (4.4\%). Among women, heterosexual transmission accounted for $80.3 \%$ of new diagnoses. Regarding the place of origin, the $32.5 \%$ of new cases of HIV infection in men were, especially, immigrants from Latin America and sub-Saharan Africa, and in the case of women, more than half of the new diagnoses were immigrants. Since the beginning of the AIDS epidemic, 84.043 of the cases have been reported, peaking in the $90 \mathrm{~s}$ and progressively decreasing until today, nearly twenty years after the introduction of antiretroviral treatments [3].

\section{Mortality in Patients with HIV/AIDS}

By monitoring deaths of HIV / AIDS, it can be seen that the decrease in AIDS deaths among men begins in 1996, and a year later a general decline occurs in both sexes, thus, HIV / AIDS are no longer among the leading causes of death. This highlights the impact of antiretroviral treatments [4,5]. In 2005 the number of deaths caused by HIV reached 1.7 million worldwide, gradually declining to 1.3 million deaths in 2013[6]. Several studies in different social contexts indicate the relationship of early mortality with the delayed diagnosis of the disease and the moment when the treatment begins [7]. It is noteworthy that despite the gratuity of HIV testing, almost half of the cases diagnosed for the first time in 2013 showed a delayed diagnosis [3]. Death rates of HIV/AIDS remain higher in men than in women. In relation to 2012 , the number of deaths in 2013 decreased by $14.8 \%$, the average age was of 49.4 years old, and mortality rates were higher in men than in women (Figure 1), being observed a tendency toward chronic disease, affecting the middle-class youth [8]. The impact of HIV/AIDS infection as a determinant of premature death measured in YPLL also decreased [9]. No differences were found regarding mortality and survival among IDUs and other forms of contagion [10].

\section{Vulnerable Population}

Currently, the group at risk of HIV infection consists of men aged between 20 and 35 who have risky sex behaviors, with a diverse social and cultural profile [11]. The groups with higher levels of vulnerability include the penitentiary population, prostitutes and immigrants; giving the fact that female prostitution is exercised basically by immigrant women, mostly of them in an irregular administrative situation [12,13]. Several studies at Spanish prisons population report the existence of high rates of HIV infection, although they are variable depending on the source ( 12.05 to $24.3 \%)$ They also observe that confection is common, especially with infections caused by the hepatitis $\mathrm{C}$ virus [14]. In the period of greatest growth of HIV, there was a prevalence of infected prisoners, of $25-40 \%$, and the Penitentiary Administration planned a hospital care network along with the National Health System. The use of these resources has been declining as the treatments were more effective [15]. The prevalence of HIV/AIDS is similar for women in prostitution and high-risk heterosexual women; however, the prevalence in MSM prostitutes is much higher than in MSM not prostitutes. Moreover, the prevalence of HIV in Spanish prostitutes is higher than the found in immigrants. In addition, there is an Increase of women in prostitution because of the economic situation in the country and as a result, possibly more likely to have risky sexual behavior [10]. While the presence of immigrants affected by HIV has not been at the origin of the epidemic and it is not the cause of its maintenance, it must be taken into consideration because (their) treatment is a measure of prevention of morbidity and mortality for this cause [16]. In addition, it has been reported the existence of clinical and epidemiological differences compared to the native population [17-19]. They are mostly from South America and sub-Saharan Africa, they are young; (Figure 2) mostly women and they are in a more vulnerable social situation than the local population. New diagnoses are made at an advanced stage of the disease, especially in men. Among foreign women, those from Africa present a significantly higher prevalence than women from other regions [20]. Homosexual/bisexual men are prevailing among those from Latin America. The decline in AIDS cases since the introduction of antiretroviral treatments is less evident in the immigrant population, possibly due to regulatory changes in health care that occurred in 2012

*Corresponding author: Consuelo López Fernández, University of Cadiz Jerez de la Frontera, Cádiz Spain, Tel: 34617321121; E-mail: consuelo.lopez@uca.es

Received October 23, 2015; Accepted November 13, 2015; Published November 25, 2015

Citation: Fernández CL, Garcia JMP, Cano MJS, Cabezas VP, Hervas MA (2015) Social Care for HIVIAIDS Patients in Spain. Health Care Current Reviews 3: 148. doi: $10.4172 / 2375-4273.1000148$

Copyright: @ 2015 Fernández CL, et al. This is an open-access article distributed under the terms of the Creative Commons Attribution License, which permits unrestricted use, distribution, and reproduction in any medium, provided the original author and source are credited. 
Citation: Fernández CL, Garcia JMP, Cano MJS, Cabezas VP, Hervas MA (2015) Social Care for HIVIAIDS Patients in Spain. Health Care Current Reviews 3: 148. doi: 10.4172/2375-4273.1000148

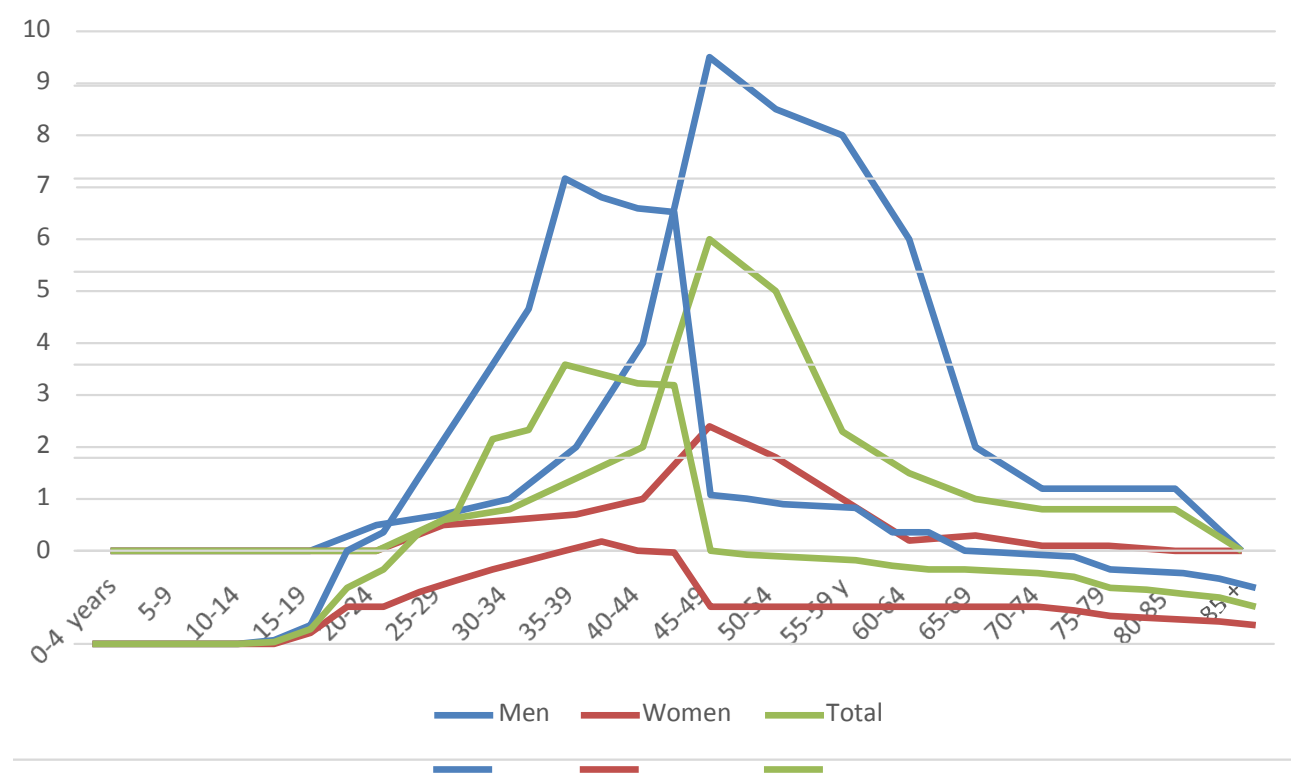

Figure 1: Death rates x 100,000 inhabitants, by age groups, year 2013.

2013

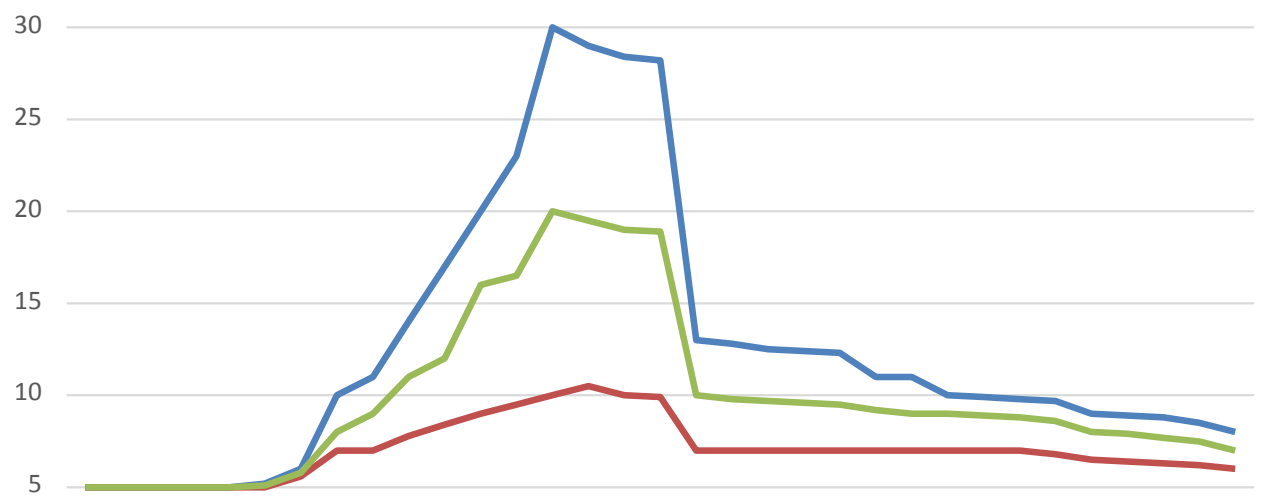

0

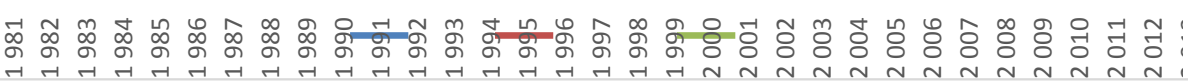

Men Women Total

Figure 2: Mortality from HIVIAIDS (ratesx1000,000 inhabitants), total and by sex, 1981.

resulting from the economic crisis. These changes limited the access to health care for undocumented migrants [21].

\section{Social-Health Coordination}

As a result of the HIV/AIDS, the National Committee for Coordination and Follow-up of Programs for AIDS Prevention was established in 1987. This structure assumes issues related to research, epidemiology, prevention and treatment strategies. Alongside this National Plan on AIDS, there are autonomic AIDS programs derived from the regional structure of the country. Currently, the Strategic Plan 2013-2016 for Prevention and Control of HIV infection and other sexually transmitted infections is in full development [22].
From the point of view of the coverage of the health needs of patients with HIV/AIDS, in Spain there is a public health system that covers the treatment and health care. In relation to other types of coverage, there are adequate financial supports to each situation. Thus, in 1993 it began to offer aid to those affected by HIV who acquired the disease as a result of actions carried out in the public health system before the mandatory HIV testing (blood transfusions or treatment with blood products). This aid was an attempt to ease the non- health consequences of the disease and its beneficiaries are not only the patients but also their families: spouses and children as well as adults who depend on those affected [23-27]. 
Citation: Fernández CL, Garcia JMP, Cano MJS, Cabezas VP, Hervas MA (2015) Social Care for HIVIAIDS Patients in Spain. Health Care Current Reviews 3: 148. doi: 10.4172/2375-4273.1000148

Page 3 of 5

\section{Effectiveness of Antiretroviral Treatment}

In the world, HIV infections fell by approximately 40 per cent between the years

2000 and 2013, due to the efficiency of the antiretroviral treatment, although, the knowledge of HIV and HIV prevention remains low among young people [24]. In Spain there is a universal access policy to antiretroviral treatment. Early diagnosis of HIV infection enables a treatment that reduces hospital morbidity and mortality and possibilities of transmission. The importance of early initiation of the treatment is especially important for pregnant women to protect children's health. Because of the apparent effectiveness of antiretroviral treatments, it has achieved a better quality of life and decreased mortality so that the proportion of people infected with HIV over 50 years has increased. This circumstance is a new challenge to health care and its coordination with social assistance as aging and dependency situations are appearing in different degrees making the care coordination necessary to consider a possibility of comprehensive care for people with this diagnosis. In this context, the need to develop economic measures to support people in situations of dependency was raised, including the HIV-AIDS population that is aging. Thus, among people infected with HIV, the proportion of over 50 years old has increased from $7.7 \%$ in 2000 to $29.9 \%$ at 2012 , which represents a new challenge for both health and social needs of this group of patients [22]. And we contemplate their inclusion among candidates for benefits of the Law of Dependency since at times, to establish itself as a chronic illness, the chronicity and dependence binomial appears not only in health, but also in social needs [25].

\section{HIV Carriers and AIDS Patients' Social Care}

The functions of prevention and health promotion on AIDS are conducted through information campaigns of the Ministry of Health, Social and Equality Services and the Health Councils of the Autonomous Communities [26]. The patients referred from primary health care centers, health institutions and units of care of drug addicts, are diagnosed and treated in hospitals existing intervention protocols, following-ups and coordination between primary health care and hospital care. Specialist care is done at an infection's outpatient level, where the prison population are also addressed, assisting with police protection. Patients who because of their advanced disease require specialist (transfusions, treatments) and ongoing care but not fulltime inpatient confinements are treated at day hospitals (Figure 3). This health resort reduces hospital admissions and economic cost. When the patient enters an advanced stage of the disease there is home care available and when the demand on health care is permanent the hospitalization is required at the Infectious Unit. In this situation, patients need a lot of health care and care giving; complex and free drug treatment of universal dispensing, with Pharmacy Services of hospitals that provide AIDS patients requiring specific drugs, in addition to antiretroviral. AIDS have become a chronic disease, affecting a population that is aging, with opportunistic infections, subjected to pharmacological treatment not without adverse effects, which have complex care needs, the figure of the Case Manager Nurse was created for following-up and as an unifying element of the patient's needs and coordination of resources [27]

\section{Social Interventions to Address AIDS Patients}

There are no specific social resources no social intervention programs for AIDS patients, who are usually included in the Program of Care to Marginalization and it grants sporadic aids for the terminally ill care or home care. Under Spanish law, HIV/AIDS is not always disabling. Thus, only those who have been granted a degree of disability

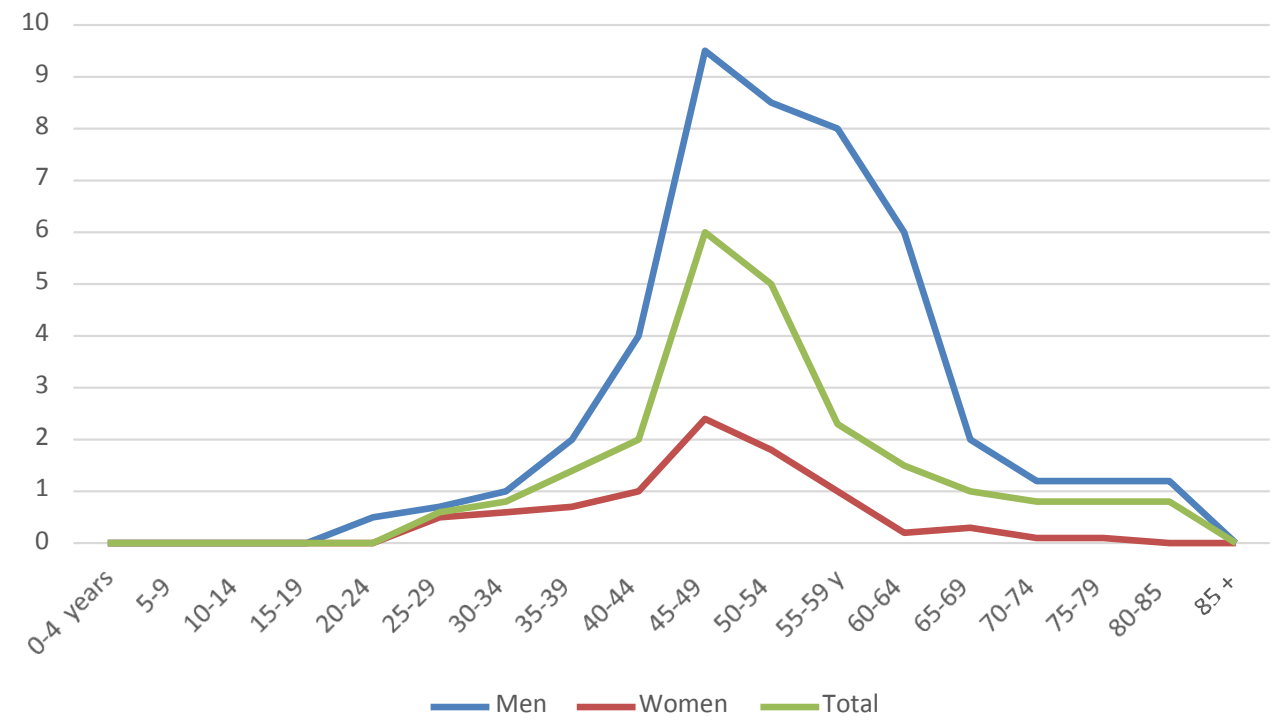

Figura 3: Death rates $\times 100,000$ inhabitants, by age groups, year 2013

\begin{tabular}{|c|c|c|c|c|c|c|c|c|c|c|c|c|c|}
\hline & $80-82$ & $90-92$ & 00-02 & 2003 & 2004 & 2005 & 2006 & 2007 & 2008 & 2009 & 2010 & 2011 & 2012 \\
\hline Men & 0 & 423,93 & 187,28 & 165,07 & 156,84 & 138,27 & 116,23 & 113,87 & 97,42 & 83 & 76,79 & 70,19 & 59,42 \\
\hline Wemen & 0 & 90,19 & 49,22 & 48,04 & 37,52 & 38,22 & 35,36 & 30,81 & 30,31 & 24,88 & 22,71 & 20 & 21 \\
\hline
\end{tabular}

Tabla 1: Years of potential life lost (YPLL) for HIV / AIDS by sex. Spain 1980-02; 1990-1902; 2003 -2012 age-standardized rate per 100000 population in Europe h. 
equal to or greater than $33 \%$ can benefit from protection measures and/or positive discrimination established by the law on grounds of disability. It will have a minimum percentage of their jobs for persons with disabilities are set. This disability of $33 \%$ are "those adults whose CD4 counts are less than 200 in the past year and those children in class $\mathrm{C} 3$ who have a minimum percentage of $33 \%$ disability and people who are in a position of HIV and Hepatitis C virus co-infection". In other situations, the score mainly depends on the symptoms. The recognition of a degree of disability equal to or greater than $33 \%$ is related to access to social services, to a non-contributory pension in the Social Welfare system (if it reaches 65\%), certain advantages in relation to access to employment and some tax benefits [28]. In the workplace, the obligation for companies with more than 50 workers on staff to reserve $2 \%$ of percentagerisesto5\%forAdministration. Inaddition, specific types of contracts to which disabled people can access are established: promotion of permanent hiring, promotion of employment, apprenticeship contract or training contract [29]. In the same way that HIV/AIDS does not always generate disability, HIV/ AIDS does not always lead dependence, but often affects the autonomy of the individual. The Law on the Promotion of Personal Independence and Service to Persons in a Situation of Dependency focuses primarily on the Activities of Daily Living to establish the conditions of access to benefits and financial aids $[25,29]$. Therefore, people with HIV/AIDS have access to benefits derived from the System for Personal Autonomy and Care of Dependent Adults (SAAD), if previously have recognized any of the degrees of dependency under the Act, by requiring support for the basic daily life activities [25]. As for other financial benefits, due to the age at which the disease appears, often these patients have not contributed enough to gain access to contributory pensions managed by the National Institute of Social Welfare and request non-contributory pensions.

\section{Impact of the Economic Crisis on Health and Social Care to Hiv/Aids}

The economic crisis suffered by our country has become necessary the emergence of other players, other than those from the state who have gained prominence in the attention and intervention of social problems (non- governmental organizations, religious institutions and mainly, families) One of the measures taken by the Spanish government in times of economic crisis that hit the country recently, was the restriction of the right for illegal immigrants in Spain to health care under the same conditions as indigenous, soon they entitled to emergency health care if they are under 18 or pregnant women. Epidemiological studies underscore the importance to the population level of treatment and prevention of both morbidity and mortality and the transmission of the virus, so predictably increased morbidity and mortality from HIV/ AIDS after this restrictive measure [30,31]. The decline in AIDS cases in Europe has been lower among immigrants, there is a delay in diagnosis of multi causal origin and possibly administrative, cultural or language barriers that make the understanding of health claims is inadequate and occurs an abandonment of treatment and breach of health checks [32].

\section{Life Quality of HIV/AIDS Patients}

At the present time, it is considered that the HIV/AIDS infection transcends the biological level and has economic, socio-cultural, psychological and environmental consequences for patients. It highlights the need to broaden the approach to the process beyond the classics of morbidity, mortality and disability. In that sense, there is interest in analyzing the dimensions that can affect adherence, particularly the quality of life related to health [33]. An important quality of life of people with HIV/AIDS factor is the support of informal caregivers. While commonly infected with HIV it is to have autonomy adults, children and adolescents need to be maintained. However, in both cases, effective management of symptoms and adherence to treatment is necessary. Achieve adequate symptom management is important because some of these symptoms may affect the welfare and reduce adherence to antiretroviral treatment. The management of this everyday experience is enhanced by the presence of caregivers who provide the person the necessary support to persist in care behaviours [34]. Moreover, despite antiretroviral therapy, many people have symptoms related to the disease have opportunistic infections, comorbidity and show side effects of medication. In these circumstances often the capacity for autonomy is reduced, requiring the help of a caregiver. Informal caregivers play a key role in social life, and support the physical and emotional well-being of people with chronic disease, in fact, a source of social support. In the case of HIV/AIDS informal caregivers it has been associated with a slowdown in the progress of the disease and improved quality of life [35]. In general caregiving is a physical, psychological and social cost, and requires resources, personnel, financial and material. In the subgroup populations of people with HIV/AIDS disadvantaged, caregivers often have fewer resources to perform its role placing them at greater risk of overload (fatigue experienced by care), this can be increased if the person has maintained a stigmatizing condition presents disruptive behaviour or abuse of substances [34]. It has come to consider care for people with HIV similar to that offered to the elderly AIDS as it extends over time and often leads to health problems for the caregiver own [36]. In Spain, as in other developed countries, there are few studies designed specifically for caregivers of people with HIV / AIDS. According to existing data, the profile of informal caregivers of people with HIV / AIDS is a woman with an average age of 50, who is usually the mother or partner of the person primarily affected and aid in tasks related to the management home and offering company [37]. Providing this assistance has meant substantially modify their usual activities, being affected their care, their health and in some cases their economic conditions. Health problems in the caregiver are greater the higher the gravity of the situation of people with HIV / AIDS still receive less social support than caregivers who support people with another situation or pathology [37].

\section{References}

1. Fernández Sierra MA, Gómez Olmedo M, Delgado Rodríguez M, et al. (1990) Infección por el virus de la inmunodeficiencia humana en la población española (II). Metaanálisis de las tendencias temporales y geográficas. Med Clin (Barc) 95: 366-71.

2. Diez M, Oliva J, Sánchez F, Vives N, Cevallos C et al.(2012) Incidencia de nuevos diagnósticos de HIV en España, 2004-2009. Gac Sanit 26: 107-115.

3. Instituto de Salud Carlos III (2014) Ministerio de Sanidad, Servicios Sociales e Igualdad. Ministerio de Economía y Competitividad. Vigilancia epidemiológica del SIDA en España. Actualización 30 de junio de.

4. Martínez de Aragón MV, y Llácer A (2001) Mortalidad en España en 1997 Mortalidad general, principales causas de muerte y de años potenciales de vida perdidos. Mortalidad por sida. SEMERGEN 27: 377-84.

5. Moreno-Iribas C, Floristán Y y Egüés N (2006) Tendencias recientes de las principales causas de muerte en navarra. 1995-2004. Salud Púbica y Administración Sanitaria 29: 399-414.

6. Murray CJ, Ortblad KF, Guinovart C, Lim SS, Wolock TM, et al. (2014) Global, regional, and national incidence and mortality for HIV, tuberculosis, and malaria during 1990-2013: a systematic analysis for the Global Burden of Disease Study 2013. Lancet 13: 1005-1070.

7. Silverman-Retana O, Bautista-Arredondo Serván-Moru E y LozanR (2015) Mortalidad temprana por sida en México durante el periodo 2008-2012. Salud Pública de México 57: 119-26. 
Citation: Fernández CL, Garcia JMP, Cano MJS, Cabezas VP, Hervas MA (2015) Social Care for HIVIAIDS Patients in Spain. Health Care Current Reviews 3: 148. doi: 10.4172/2375-4273.1000148

8. Instituto de Salud Carlos III, Ministerio de Sanidad, Servicios Sociales e Igualdad (2015) Mortalidad por HIVIAIDS en España, año 2013. Evolución 1981-2013. Plan Nacional sobre el Sida. Madrid.

9. Instituto Nacional de Estadística (2014) [Consultado 15 Octubre 2015] Disponible en.

10. Bermúdez-Tamayo C, Martín-Martín, y Ruiz-Pérez I (2009) Años de vida ajustados por discapacidad de las personas con infección por HIVIAIDS usuarias de drogas por vía parenteral. Trastornos adictivos 11: 44-50.

11. 11. European Centre for Disease Prevention and Control/WHO Regional Office for Europe. (2010) HIVIAIDS surveillance in Europe 2009. Stockholm: European Centre for Disease Prevention and Control.

12. Folch C, Casabona J, Sanclemente C, Esteve A, González V y Grupo HIVITS TS (2014) Tendencias de la prevalencia del HIV y de las conductas de riesgo asociadas en mujeres trabajadoras del sexo en Cataluña. Gac San 28: 196202

13. Médicos del Mundo [Intenet]. Programas para personas en situación de prostitución. Memoria 2012. (Consultado el 19/10/205/). Disponible en.

14. Sainz de la Hoya P, Bedia M, Murcia J, Cebriá J, Sanchez-Payá j y Portilla J (2005) Factores predictivos de infección por el HIV, VHC y coinfección en la población reclusa de una prisión española. Enferm Infecc Microbiol Clin 23: 53-7.

15. García J, Vera E, González F (2001) Utilización de recursos hospitalarios por la población reclusa antes y después de la introducción de los tratamientos con inhibidores de las proteasas. ¿Existen cambios? Rev Esp Sanid Penit 3: 65-71.

16. Montanet JSC, Lima VD, Barrios R, Yip B, Wood E et al. (2010) Association of highly active antiretroviral therapy coverage, population viral load, and yearly new HIV diagnoses in British Columbia, Canada: a population-bases study. Lancet 376:532-.539

17. Hernando A, Garcia-Cerrada C, Pulido F, Rubio R, Hervás R et al. (2007) Infección por el HIV en inmigrantes: diferencias clínico- epidemiológicas con la población autóctona en un área de salud de la Comunidad de Madrid (20012004). Enferm Infecc Microbiol Clin 25: 441-445.

18. Caro-Murillo AM, Castilla J, del Amo J (2010) Epidemiología de la infección por HIV en inmigrantes en España: fuentes de información, características, magnitud y tendencias. Gac San 24: 81-8.

19. Llenas-García J, Rubio R, Hernando A, Fiorante S, Maseda D (2012) Características clínico-epidemiológicas de los pacientes inmigrantes con infección por el HIV: estudio de 371 casos. Enferm Infecc Microbiol Clin 30 441-51.

20. Instituto de Salud Carlos III. Ministerio de Sanidad y Política Social. Situación epidemiológica del VI//sida en inmigrantes. Agosto, 2009.

21. Pérez-Molina JA (2012) Pulido F y Comité de expertos del Grupo para el Estudio del Sida (GESIDA) de la Sociedad Española de Enfermedades Infecciosas y Microbiología Clínica (SEIMC). Evaluación del impacto del nuevo marco legal sanitario sobre los inmigrantes en situación irregular en España: el caso de la infección por el virus de la inmunodeficiencia humana. Enferm Infecc Microbiol Clin 30: 4728.

22. Ministerio de Sanidad, Servicios Sociales e Igualdad (2015) Plan Estratégico de Prevención y Control de la infección por el HIV y otras infecciones de transmisión sexual 2013-2016. Sanidad.
23. Boletín Oficial del Estado (1993) Real Decreto-ley 9/1993, de 28 de mayo, sobre concesión de ayudas a los afectados por el virus de inmunodeficiencia humana, como consecuencia de actuaciones realizadas en el Sistema Sanitario Público.

24. United nation. The Millennium Development Goals Report, 2015. NewYork.

25. Boletín Oficial del Estado (2006) Ley 39/2006, de 14 de diciembre, de Promoción de la Autonomía Personal y Atención a las Personas en situación de Dependencia.

26. Boletín Oficial del Pueblo Andaluz. Informe Especial: Estudio sobre la atención sociosanitaria a los enfermos de sida en Andalucía. Defensor del Pueblo Andaluz. Diario de Sesiones de la Comisión de Salud $n^{\circ} 216$ serie A, sesión celebrada el 25-11-1998.

27. Gómez MC (2011) Intervención de la enfermera gestora de casos durante ingreso hospitalario de pacientes con infección HIV. Rev Esp Salud Pública 85: $237-44$

28. Barranco Avilés, MC (2010) Consecuencias del reconocimiento de un 33 por 100 de minusvalía para las personas que viven con HIVIAIDS. Instituto de Derechos Humanos Bartolomé de las Casas. Universidad Carlos III. Madrid.

29. BOE núm (2006 ) 299 Ley 39/2006, de 14 de diciembre, de promoción de la Autonomía Personal y Atención a las personas en situación de Dependencia. Madrid.

30. Montaner J (2012) Consecuencias nefastas para la epidemia de virus de la inmunodeficiencia humana en España raíz del nuevo marco legal sanitario sobre los inmigrantes en situación irregular: ahorra hoy y pagarás mañana. Enferm Infecc Microbiol Clin 30: 431-2.

31. Pérez-Molina JA (2015) Pulido F y Comité de expertos del Comité de experto del Grupo para el Estudio del Sida (GESIDA) de la Sociedad Española de Enfermedades Infecciosas y Microbiología Clínica (SEIMC). ¿Cómo está afectado la aplicación del nuevo marco legal sanitario a la asistencia de los inmigrantes infectados por el HIV en situación irregular en España? Enferm Infecc Microbiol Clin 33: 437-45.

32. López-Vélez R, Navarro M, Hernando A, del Amo J (2008) Infección por el HIV en inmigrantes. Enferm Infecc Microbiol Clin 26: 12-21.

33. Cardona-Arias JA, Higuita-Gutiérrez LF (2014) Impacto del HIV/SID sobre la calidad de vida: Metaabálisis 2002-2012. Rev Esp Salud Pública 88: 87-101.

34. Nicca D, Fierz K, Happ MB, Moody K Spirig R. Symptom Management in HIV/ AIDS: A Mixed Methods Approach to Describe Collaboration and Concordance Between Persons Living With HIV and Their Close Support Persons. Journal of Mixed Methods Research 6: 217- 235

35. Knowlton AR, Mitchell MM, Robinson AC, Nguyen TQ, Isenberg $S$ et al (2015) Informal HIV Caregiver Proxy Reports of Care Recipients' Treatment Adherence: Relationship Factors Associated with Concordance with Recipients Viral Suppression. AIDS Behav 19: 2123-2129.

36. Mignone J, Migliardi P, Harvey C, Davis J, Madariaga-Vignudo L et al. (2015) HIV as Chronic Illness: Caregiving and Social Networks in a Vulnerable Population. J Assoc Nurses AIDS Care 26: 235-245.

37. Fuentelsaz-Gallego, Carmen (2006) Características y calidad de vida de los cuidadores informales de enfermos de sida. Enf Clínica 16: 137-143. 